\title{
Behavioral and Neurochemical Changes Induced by Oxycodone Differ Between Adolescent and Adult Mice
}

\author{
Yong Zhang*,', Roberto Picetti', Eduardo R Butelman', Stefan D Schlussman', Ann Ho' and \\ Mary Jeanne Kreek' \\ 'The Laboratory of the Biology of Addictive Diseases, The Rockefeller University, New York, NY, USA
}

\begin{abstract}
Nonmedical use of the prescription opioid analgesic oxycodone is a major problem in the United States, particularly among adolescents and young adults. This study characterized self-administration of oxycodone by adolescent and adult mice, and how this affects striatal dopamine levels. Male C57BL/6J mice (4 or 10 weeks old) were allowed to acquire oxycodone self-administration (0.25 mg/kg per infusion) for 9 days, and then tested with varying doses of oxycodone $(0,0.125,0.25,0.5$, and $0.75 \mathrm{mg} / \mathrm{kg}$ per infusion). On completion of the self-administration study, a guide cannula was implanted into the striatum of these mice. Six days later, microdialysis was conducted on the freely moving mouse. After collection of baseline samples, oxycodone was administered i.p. (1.25, 2.5, and 5.0 mg/kg) and samples were collected for I h after each dose. Adult mice self-administered significantly more oxycodone across the doses tested. After I week, basal striatal dopamine levels were lower in mice of both ages that had self-administered oxycodone than in yoked saline controls. Oxycodone challenge increased striatal dopamine levels in a dose-dependent manner in both age groups. Of interest, the lowest dose of oxycodone led to increased striatal dopamine levels in the mice that had self-administered oxycodone during adolescence but not those that self-administered it as adults. The lower number of infusions of oxycodone self-administered by adolescent mice, and their later increased striatal dopamine in response to the lowest dose of oxycodone (not found in adults), suggest differential sensitivity to the reinforcing and neurobiological effects of oxycodone in the younger mice.

Neuropsychopharmacology (2009) 34, 912-922; doi:I0.1038/npp.2008. I34; published online 10 September 2008
\end{abstract}

Keywords: self-administration; adolescent; adult; mice; oxycodone; microdialysis

\section{INTRODUCTION}

The clinical problem of nonmedical use of opioids, such as oxycodone and hydrocodone, has become a major health concern in the United States. According to the National Survey on Drug Use and Health, this problem has escalated in recent years. Although the overall use of illicit drugs by young people has dropped by approximately $24 \%$ in recent years, an exception to this trend is the rise in nonprescription use of oxycontin (oxycodone) and vicodin (hydrocodone), with approximately $10 \%$ of high school seniors reporting illicit use of these prescription opioids (Johnston et al, 2006). Furthermore, prescription opioid analgesics (eg oxycodone and the prototypical compound, morphine) are the most commonly used and most powerful medications in pain management (Cherny, 1996; Nicholson, 2003; Shelley and Paech, 2008). Nonmedical use of prescription opioids

\footnotetext{
* Correspondence: Dr Y Zhang, The Laboratory of the Biology of Addictive Diseases, The Rockefeller University, 1230 York Avenue, Box 17I, New York, NY 10065, USA. Tel: + I 212327 8247; Fax: + I 212327 8574; E-mail: zhangyo@rockefeller.edu

Received 15 February 2008; revised 18 July 2008; accepted 22 July 2008
}

has been associated with opioid abuse and the development of addiction in some individuals.

As with other drugs of abuse, the onset of abuse of the prescription opioid oxycodone occurs mostly in adolescents and young adults. Oxycodone abuse in the adolescent is especially worrisome as adolescence is a unique developmental stage during which the central nervous system undergoes marked alteration. For example, dopamine receptors in the nigrostriatal and mesolimbic dopaminergic systems are overproduced in early adolescence (Teicher et al, 1995; Tarazi et al, 1998, 1999, 2000). $\mu$-Opioid receptor-stimulating $\left[{ }^{35} \mathrm{~S}\right]$ GTP $\gamma \mathrm{S}$ binding increased from 0.13 to $3.6 \mathrm{fmol} / \mathrm{mg}$ tissue between postnatal day (P or PND) five and adulthood (Talbot et al, 2005). During this period, exposure to oxycodone may result in neurobiological changes in the adolescent brain that may predispose an adolescent to take more opioids and increase the risk of developing addiction on subsequent re-exposure. This is in accord with reports showing that early onset of cigarettes or alcohol use increased the likelihood of using the same or other drugs of abuse (Yu and Williford, 1992; Merrill et al, 1999).

Striatal dopamine is involved in the reinforcing effects of drugs of abuse including opioids. Acute opioid administration in the adult rodent results in increases in striatal 
dopamine levels (Hemby et al, 1995; Wise et al, 1995), whereas repeated opioid administration leads to decreases in basal striatal dopamine levels (Rossetti et al, 1992; Diana et al, 1995; Gerrits et al, 2002). It is not clear yet whether effects of oxycodone on adolescent rodents are similar to those on adults.

The behavioral and neurobiological changes that occur during acute or chronic re-exposure to the widely abused opioid oxycodone are very difficult to study in human adolescents, as patients in this early stage do not often seek treatment. The current experiments were designed to study oxycodone-induced behavioral changes in adolescent and in adult mice in a self-administration model. We then examined oxycodone-induced alterations in striatal dopamine levels in these mice when they were young adults and compared the effects to those of the older mice.

\section{MATERIALS AND METHODS}

\section{Subjects}

Male adolescent and adult (4 or 10 weeks old on arrival) C57BL/6J mice (Jackson Laboratory, Bar Harbor, ME) were housed in groups of five with free access to food and water in a light (12:12 h light/dark cycle, lights on at 0700 hours) and temperature $\left(25^{\circ} \mathrm{C}\right)$ controlled room. Animal care and experimental procedures were conducted according to the Guide for the Care and Use of Laboratory Animals (Institute of Laboratory Animal Resources Commission on Life Sciences, 1996). The experimental protocols used were approved by the Institutional Animal Care and Use Committee of The Rockefeller University. The time line of self-administration and microdialysis studies and the age of mice are shown in Table 1.

\section{Self-Administration of Oxycodone}

Catheter implantation. Following acclimation for 5 days, the mice were anesthetized with a combination of xylazine $(8.0 \mathrm{mg} / \mathrm{kg}$, i.p.) and ketamine $(80 \mathrm{mg} / \mathrm{kg}$, i.p. $)$. After shaving and application of a $70 \%$ alcohol and iodine preparatory solution, incisions were made in the midscapular region and anteromedial to the forearm. A catheter approximately $6 \mathrm{~cm}$ in length (i.d.: $0.31 \mathrm{~mm}$, o.d.: $0.64 \mathrm{~mm}$ ) (Helix Medical Inc., CA) was passed subcutaneously from the dorsal to the ventral incision. After exposure of the right jugular vein, a 22-gauge needle was inserted into the vein to guide the catheter into the jugular vein. Once the catheter was inside the vein, the needle was removed and the catheter was inserted to the level of a silicone ball marker $1.1 \mathrm{~cm}$ from the end. The catheter was tied to the vein with surgical silk. Physiological saline then was flushed through the catheter to avoid clotting and the catheter then capped with a stopper. Antibiotic ointment was applied to the catheter exit wounds on the animal's back and forearm. Mice were individually housed after the surgery and were allowed 3 days of recovery (due to the limited period of adolescence in the mouse) before being placed in operant test chambers for the self-administration procedure (Zhang et al, 2006).

Intravenous self-administration chamber. The self-administration chamber ENV-307W $(21.6 \mathrm{~cm} \times 17.8 \mathrm{~cm} \times 12.7 \mathrm{~cm}$; Med Associates, St Albans, VT) was located inside a larger box (Med Associates). The front, back, and top were constructed of $5.6 \mathrm{~mm}$ polycarbonate. Each chamber contained a wall with two small holes $(0.9 \mathrm{~cm}$ diameter, $4.2 \mathrm{~cm}$ apart, $1.5 \mathrm{~cm}$ from the floor of the chamber). One hole was defined as active, the other was inactive. When the photocell in the active hole was triggered by a nose poke, the infusion pump (Med Associates) delivered an infusion of $20 \mu \mathrm{l} / 3 \mathrm{~s}$ from a $5 \mathrm{ml}$ syringe. The syringe was connected by a swivel via Tygon tubing. The infusion pump and syringe were outside the chamber. During infusion, a cue light above the active hole was illuminated. Each injection was followed by a 20-s 'time-out' period during which poking responses were recorded but had no programmed consequences. All responses at the inactive hole were also recorded. Mice were tested during the light phase of the diurnal cycle (all experiments were performed between 0800 and 1400 hours).

Table I Time Line: Age of Self-Administration and In Vivo Microdialysis in Experiment I

\begin{tabular}{|c|c|c|c|c|c|}
\hline \multirow{2}{*}{$\begin{array}{l}\text { Procedure } \\
\text { Age }\end{array}$} & \multicolumn{4}{|c|}{ Self-administration } & \multirow{2}{*}{ Microdialysis } \\
\hline & Surgery & FRI & FR3 & Dose-response & \\
\hline \multicolumn{6}{|l|}{ Adolescent } \\
\hline Postnatal day & $32-33$ & $36-40$ & $41-45$ & $46-55$ & $61-63$ \\
\hline Number of mice & 16 & $16-13$ & $12-12$ & ||$-||$ & 9 \\
\hline \multicolumn{6}{|l|}{ Average } \\
\hline Body weight (g) & 20.3 & $20.4-21.1$ & $21.6-22.1$ & $22.1-23.3$ & 23.5 \\
\hline \multicolumn{6}{|l|}{ Adult } \\
\hline Postnatal day & $75-76$ & $79-82$ & $83-87$ & 88-97 & $103-105$ \\
\hline Number of mice & 16 & $16-13$ & $13-12$ & $|2-1|$ & 9 \\
\hline \multicolumn{6}{|l|}{ Average } \\
\hline Body weight (g) & 24.9 & $24.9-25.3$ & $25.5-26.7$ & $26.2-27.4$ & 27.9 \\
\hline
\end{tabular}




\section{Procedures}

Experiment 1. oxycodone self-administration and microdialysis. A 2-h self-administration session was conducted once a day. Each day, mice were weighed and heparinized saline $(0.01 \mathrm{ml}$ of $30 \mathrm{IU} / \mathrm{ml}$ solution) was used to flush the catheter to maintain patency. During self-administration sessions, mice in the oxycodone (Sigma, St Louis, MO) groups were placed in the self-administration chamber and a nose poke through the active hole led to an infusion of oxycodone $(0.25 \mathrm{mg} / \mathrm{kg}$ per infusion) under an FR1 schedule for 5 days. The FR schedule was then changed from FR1 to FR3. The FR3 schedule was maintained until the mice reached the full self-administration criteria (which was reached within 4 days) of (1) stable intake, defined as three consecutive sessions in which the total number of infusions per session remained within $20 \%$ of the mean of these three consecutive sessions; (2) the percent responses on the active hole were greater than $70 \%$ of the total responses in these three consecutive sessions; and (3) the minimum infusion number was eight per session in the three sessions. Drug doses were titrated every 3 days for individual animals to follow changes in body weight.

Once the mice reached the full self-administration criteria, the doses of oxycodone were presented in an ascending $(0,0.125,0.25,0.5$, and $0.75 \mathrm{mg} / \mathrm{kg}$ per infusion), then a descending order $(0.75,0.5,0.25,0.125$, and $0 \mathrm{mg} / \mathrm{kg}$ per infusion), one dose per session with each dose tested in two separate sessions. A Latin square design was not used in this experiment because neurochemical measurements were to be conducted in the same mice following the selfadministration study (but see Experiment 2). Mice in the control groups received yoked saline infusions during all sessions (saline was infused in the control mouse whenever the oxycodone mouse self-administered oxycodone).

At the end of the experiment, only data from mice that passed a catheter patency test (defined as loss of muscle tone within a few seconds after administration of a short-acting anesthetic) with injection of $30 \mu \mathrm{l}$ of ketamine $(5 \mathrm{mg} / \mathrm{ml})$ (Fort Dodge, IA) were included in the analysis of self-administration data. Of a total 32 mice that started the study, 24 mice reached full acquisition criteria. Of these 24 mice, 22 finished the dose-response study and passed the catheter patency test.

\section{Microdialysis Studies}

Mice that finished the self-administration study were then studied by in vivo microdialysis. A total of 20 mice received guide cannula implantation, and 18 mice were used in the final analyses; two were not included due to loss of their cannula.

Guide cannula implantation. One day after the last selfadministration session, mice were anesthetized with a combination of xylazine $(8.0 \mathrm{mg} / \mathrm{kg}$, i.p.) and ketamine $(80 \mathrm{mg} / \mathrm{kg}$, i.p. $)$ and were placed in a stereotaxic frame modified for the mouse (David Kopf, Topanga, CA) for implantation of a guide cannula. The guide cannula (BAS, West Lafayette, IN) was implanted into the striatum (coordinates from Bregma: $A=0.65 \mathrm{~mm}, L= \pm 2.00 \mathrm{~mm}$, and $V=3.00 \mathrm{~mm}$ (Franklin and Paxinos, 1997) where nigrostriatal and mesolimbic dopaminergic terminals are located, involved in the rewarding effects of drugs of abuse. The guide cannula was fixed to the skull by dental acrylic. Mice were allowed 5 days to recover from surgery before microdialysis.

In vivo microdialysis. On the day before each dialysis experiment, mice were placed into individual microdialysis chambers with free access to food and water. Dialysis probes $(2.0 \mathrm{~mm}$; BAS $)$ were then lowered into the striatum. Probes were perfused with artificial cerebrospinal fluid (CMA, North Chelmsford, MA) overnight at a rate of $1.0 \mu \mathrm{l} /$ min. Following the overnight stabilization period (15-16h), basal levels of dialysate were collected from the freely moving mice every $20 \mathrm{~min}$ for $1 \mathrm{~h}$ at a $1.0 \mu \mathrm{l} / \mathrm{min}$ flow rate. After collection of baseline samples, the mice that had previously self-administered oxycodone received oxycodone injections i.p. in an ascending order $(1.25,2.5$, and $5.0 \mathrm{mg} / \mathrm{kg}$ at hourly intervals), whereas yoked saline controls received saline injections in the same pattern. Dialysate samples were collected every $20 \mathrm{~min}$ throughout the oxycodone administration period and for $1 \mathrm{~h}$ after the last injection. Samples were frozen and stored at $-80^{\circ} \mathrm{C}$ before dopamine analysis (Zhang et al, 2001).

Determination of dialysate dopamine levels. HPLC with electrochemical detection (ESA, North Chelmsford, MA) was used to measure dopamine concentration in the dialysates. The HPLC system consisted of an ESA 540 autosampler, an ESA 582 solvent delivery system, a reverse phase C18 column, and an ESA microdialysis cell (model 5014B). The MD-TD mobile phase (10\% acetonitrile) was purchased from ESA and was delivered at a rate of $0.5 \mathrm{ml} /$ min. Chromatograms were integrated and compared with standards using the ESA 501 chromatography system (Zhang et al, 2001).

Histological verification of probe placement. Mice were decapitated following brief $\mathrm{CO}_{2}$ exposure at the end of the microdialysis study, and their brains were removed for histological evaluation. Frozen sections of $20 \mu \mathrm{m}$ were cut to verify the correct placement of dialysis probes following acetylcholinesterase labeling (Franklin and Paxinos, 1997). Figure $4 \mathrm{~b}$ shows photomicrographs of a tissue section from the brain of the representative adolescent and adult mice used in this study, showing probe placement in the striatum.

Experiment 2. oxycodone self-administration and extinction. Experiment 2 was conducted to determine whether there were any differences in a dose-response study with a Latin square design, and whether there were differences during extinction between adolescent and adult mice in oxycodone self-administration. Adolescent $(n=6)$ and adult $(n=6)$ mice received the same surgical procedure described above in Experiment 1.

Acquisition: The acquisition testing was also conducted as described in Experiment 1. Subsequently, an oxycodone dose-response curve was determined with a Latin square design. The testing doses of oxycodone were the same as in 
Experiment 1, but each dose was tested once before extinction sessions.

Extinction: Extinction conditions were the same as the oxycodone self-administration sessions with the exception that nose poking at the active hole resulted in the infusion of saline instead of oxycodone. Mice were given seven extinction sessions.

\section{Data Analysis}

To evaluate the significance of differences between adolescent and adult mice in the acquisition of oxycodone selfadministration, a three-way analysis of variance (ANOVA), age $\times$ hole $\times$ session, with repeated measures on the last factor, was conducted separately for the FR1 and FR3 schedules. To examine the differences between age groups in self-administration across the five doses of oxycodone, from 0 to $0.75 \mathrm{mg} / \mathrm{kg}$ per infusion, a two-way ANOVA, age $\times$ dose, was used with repeated measures on the second factor. To evaluate the differences in basal levels of extracellular dopamine induced by prior oxycodone selfadministration, a two-way ANOVA was used, preexposure (oxycodone self-administration $v s$ yoked saline) $\times$ age. Finally, to examine the effect of age during oxycodone self-administration on changes in dopamine levels after oxydocone challenge, a two-way ANOVA, age $\times$ dose, with repeated measures on the second factor, was used, followed by a planned comparison of age groups at the first dose of the oxycodone challenge $(1.25 \mathrm{mg} / \mathrm{kg})$. Regression was used to examine the relationship between total amounts of oxycodone self-administration with increases in dopamine levels induced by subsequent experimenter administration of oxycodone. The self-administration behavior and nose pokes during extinction in Experiment 2 were examined by two-way ANOVA with repeated measures. The criterion for significance is $p<0.05$.

\section{RESULTS}

\section{Experiment 1: Oxycodone Self-Administration and Microdialysis Study}

Age differences in the acquisition of oxycodone selfadministration. The numbers of self-administered infusions of oxycodone $(0.25 \mathrm{mg} / \mathrm{kg}$ per infusion) by both adolescent and adult mice during the acquisition phase FR1 and FR3 are shown in Figure 1. During the FR1 phase, three-way ANOVA, age $\times$ hole $\times$ session, revealed a significant main effect of age, $\mathrm{F}(1,12)=19.01, p<0.001$; adolescent mice self-administered significantly less oxycodone (nose pokes at the active hole) than the adult mice. Nose poking at the active hole was significantly more than at the inactive hole across both age groups, $F(1,12)=88.62$, $p<0.000001$. There were no significant differences across the sessions. However, there was a significant age $\times$ hole interaction, $\mathrm{F}(1,12)=10.93, p<0.01$ and a significant hole $\times$ session interaction, $\mathrm{F}(4,48)=5.25, p<0.005$. During the FR3 phase, three-way ANOVA, age $\times$ hole $\times$ session, revealed no significant difference between the two age groups, $\mathrm{F}(1,12)=4.19, p=0.063$. There was a significant difference between nose poke at the active hole $v s$ the inactive hole, $\mathrm{F}(1,12)=151.85, p<0.000001$. There were significant differences across the sessions, $F(3,36)=16.29$, $p<0.000001$ and a significant hole $\times$ session interaction, $\mathrm{F}(3,36)=20.41, p<0.000001$.

It should be noted that, when the schedule was changed from FR1 to FR3, the total intake for adults was reduced from $2.5,4,3,4.4$, and $4.4 \mathrm{mg} / \mathrm{kg}$ throughout the five sessions during FR1 to $2.2,2.5,2.7$, and $2.8 \mathrm{mg} / \mathrm{kg}$ during FR3, a reduction in the total intake in adult animals. In contrast, the total intake of oxycodone by adolescent mice was from 1.7, 1.3, 1.7, 1.7 to $2.1 \mathrm{mg} / \mathrm{kg}$ in FR1 to 2.1, 1.3, 2.3, 2.5 to $2.4 \mathrm{mg} / \mathrm{kg}$ in FR3, showing an increase.

Patterns of responding under FR3 schedules for adolescent and adult mice. Typical patterns of responding under the FR3 schedule for adolescent and adult mice are shown in Figure 2. Each vertical mark on the horizontal time line indicates delivery of a single oxycodone infusion.

Age differences in oxycodone self-administration in the dose-response study. Following the acquisition phase, a dose-response study was carried out in the adolescent and adult mice to determine whether age difference would affect oxycodone self-administration under an FR3 schedule over a range of doses. Figure 3 shows the number of selfadministered oxycodone infusions at five doses of oxycodone $(0,0.75,0.5,0.25$, and $0.125 \mathrm{mg} / \mathrm{kg}$ per infusion), mean \pm SEM of two sessions (ascending and descending) at each dose, in both the adolescent and adult mice. The numbers of infusions that would have been received if nose pokes at the 'active hole' had led to drug delivery are shown for the controls groups, although they actually received yoked saline infusions. Three-way ANOVA, age $\times$ dose $\times$ order, showed that adolescents self-administered fewer oxycodone infusions than adults across doses, $\mathrm{F}(1,12)=12.65, p<0.005$. There was a significant main effect of dose, $\mathrm{F}(4,48)=50.06, p<0.000001$, and there was a significant age $\times$ dose interaction, $\mathrm{F}(4,48)=5.80, p<0.001$, with the difference between the adolescents and adults most pronounced in the lower doses. Across the doses tested, the total dose per session of oxycodone self-administered ranged from 1.125 to $8.25 \mathrm{mg} / \mathrm{kg}$ in adult mice and from 0.625 to $5 \mathrm{mg} / \mathrm{kg}$ in adolescent mice.

Effects of oxycodone self-administration on striatal dopamine levels between the two age groups. Basal dopamine levels and oxycodone-induced increases in dopamine levels in the striatum of mice that had selfadministered oxycodone and in their yoked saline controls are shown in Figure 4a. The basal striatal dopamine levels range from 3.41 to $3.92 \mathrm{nM}$ in mice exposed to saline during adolescence and from 4.19 to $4.24 \mathrm{nM}$ in mice previously exposed to saline as adults. After oxycodone self-administration, basal striatal dopamine levels range from 1.88 to $2.11 \mathrm{nM}$ in mice exposed to oxycodone during adolescence and $1.46-1.61 \mathrm{nM}$ in mice exposed as adults.

The effect of prior oxycodone self-administration on basal dopamine levels was examined by two-way ANOVA of mean basal levels across three samples, preexposure $\times$ age. There was a significant effect of preexposure, $\mathrm{F}(1,14)=100.01, p<0.000001$; mice that had self-adminis- 
Active hole
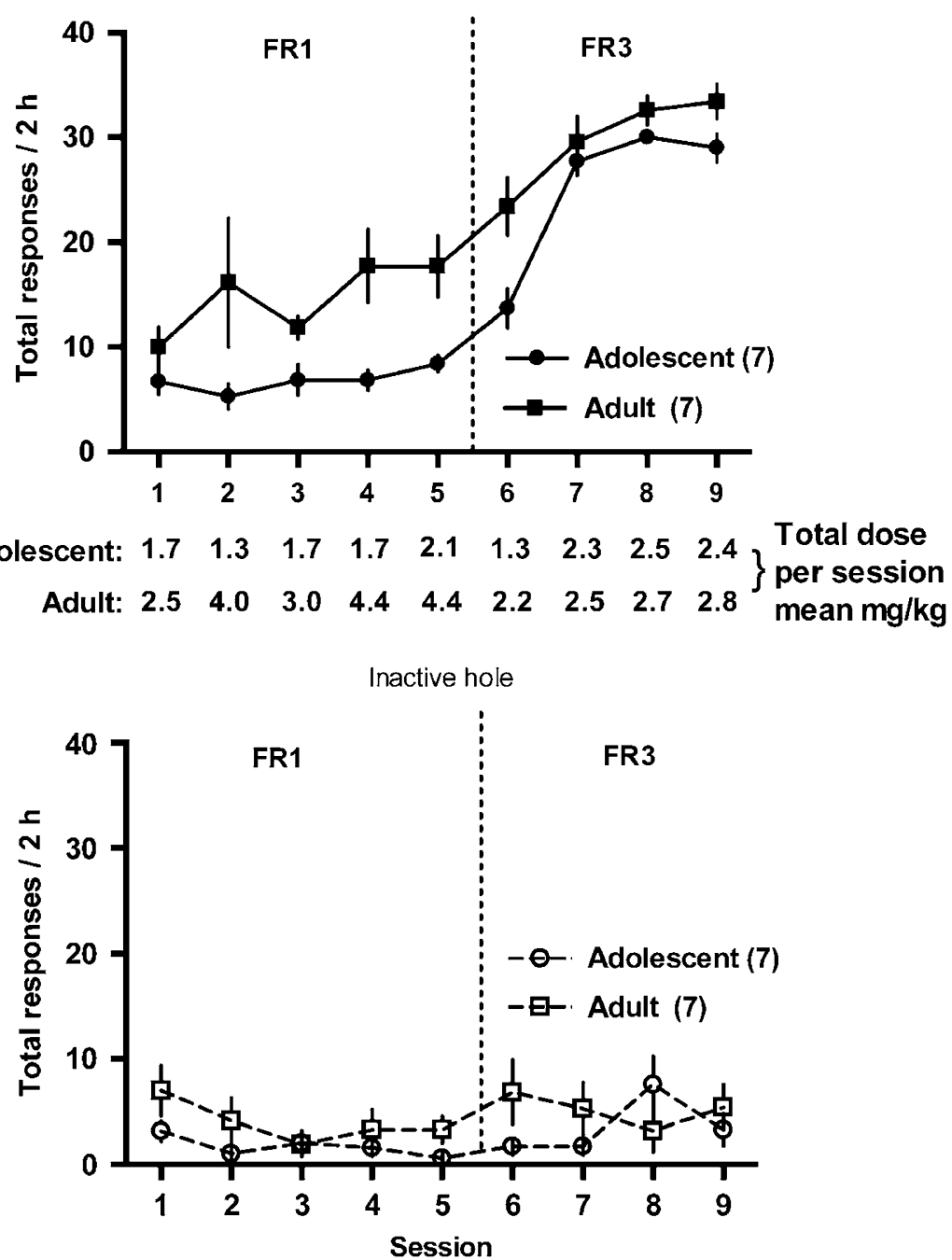

Figure I The number of self-administered infusions of oxycodone $(0.25 \mathrm{mg} / \mathrm{kg}$ per infusion $)$ by both adolescent and adult mice during the acquisition phase with FRI and FR3 schedules of reinforcement. During the FRI phase, three-way analysis of variance (ANOVA), age $\times$ hole $\times$ session, revealed a significant main effect of age, $F(I, I 2)=19.0 I, p<0.00 I$; adults self-administered more infusions of oxycodone than adolescents. During the FR3 schedule, there was no significant main effect of age groups, $F(I, I 2)=4.19, p=0.063$.

Time (min)

$\begin{array}{llll}\text { FR3 } & 30 & 60 & 90\end{array}$

Adolescent

\begin{tabular}{l|l|l|l|l|l|l|}
\hline 1 &
\end{tabular}

Adult

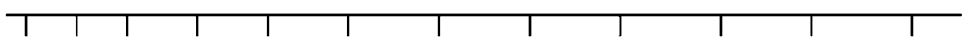

Figure 2 The typical patterns of responding under the FR3 schedules for adolescent and adult mice. Each vertical mark on the horizontal time line indicates delivery of a single oxycodone infusion.

tered oxycodone showed significantly lower basal dopamine levels than saline-yoked controls which had received only saline infusions. There was a significant interaction of preexposure $\times$ age, $\mathrm{F}(1,14)=5.41, p<0.05$, which can be seen in Figure 5a.
Then, to examine the effect of oxycodone administration on striatal dopamine levels in both groups of mice that had earlier self-administered oxycodone, we calculated change from basal dopamine for each mouse at each dose. Two-way ANOVA, age $\times$ dose, showed a significant main effect of 
Oxycodone dose response

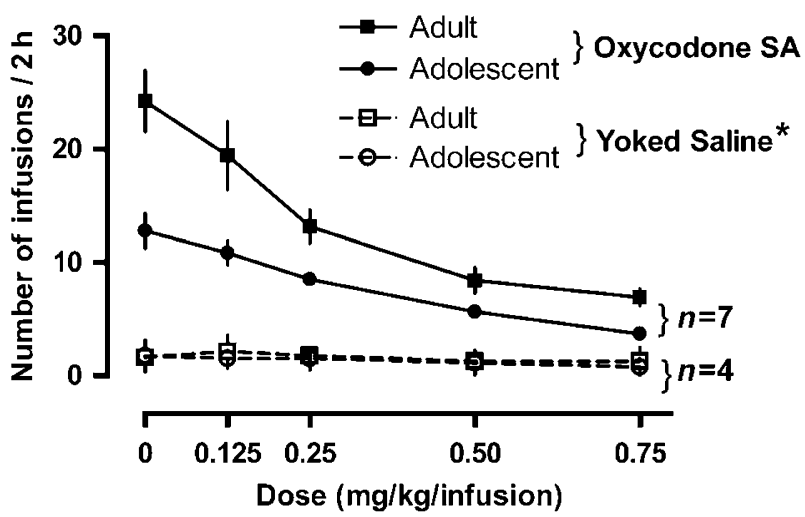

Figure 3 The number of self-administered oxycodone infusions at five doses of oxycodone $(0,0.75,0.5,0.25$, and $0.125 \mathrm{mg} / \mathrm{kg}$ per infusion), mean \pm SEM of two sessions at each dose, in both the adolescent and adult mice. Adolescents administered fewer oxycodone infusions than adults across doses, $p<0.005$. There was a significant main effect of dose, $p<0.00000$ I, and there was a significant age $\times$ dose interaction, $p<0.00$ I, with the difference between the adolescents and adults most pronounced in the lower doses. Asterisk (*) indicates the number of infusions that would have been received if the 'active hole' had led to drug delivery; control groups actually received yoked saline infusions. dose, $\mathrm{F}(2,16)=17.22, p<0.0005$ (see Figure $5 \mathrm{~b}$ ). Oxycodone increased striatal dopamine levels in a dose-dependent manner across both age groups $(p<0.05$, Newman-Keuls post hoc tests). Of interest, there was a significant difference in dopamine levels between the two age groups in response to the lowest dose of oxycodone, $\mathrm{F}(1,8)=14.18, p<0.01$ (planned comparison), with the younger mice showing an increase in striatal dopamine levels, whereas the older mice did not.

Correlation between self-administered infusions and oxycodone-induced increase in striatal dopamine levels. To further quantify the relationship between the amounts of oxycodone self-administration and subsequent oxycodoneinduced increase in striatal dopamine levels across the two age groups, we examined the correlation between the increases in dopamine in response to the three challenge doses of oxycodone and the total amount of oxycodone that had been self-administered earlier by each mouse. This analysis revealed a significant negative correlation between the total amounts of oxycodone that had been previously self-administered and increases induced by oxycodone injections in striatal dopamine levels, $r=0.642, p<0.05$ (Figure 6). The greater the amount of oxycodone self-

a

Prior Experience
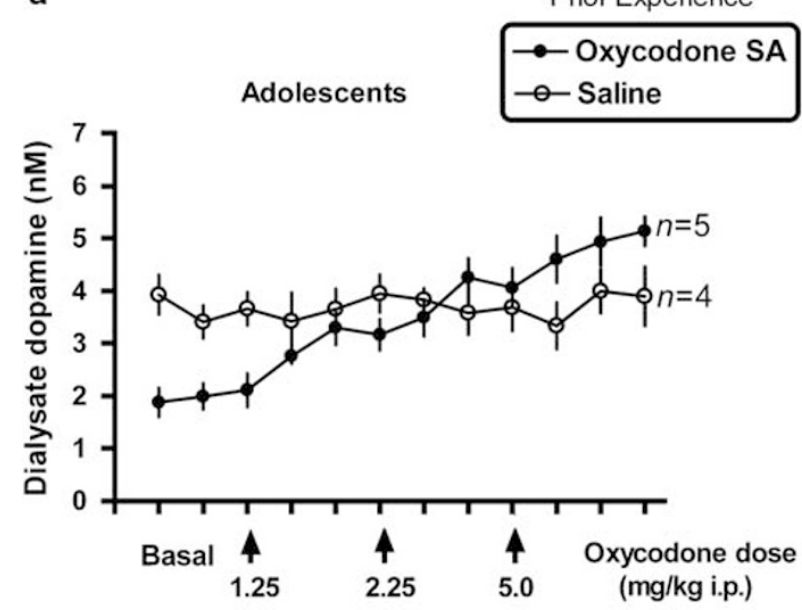

b

Adolescent

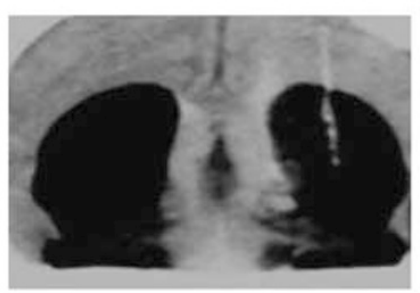

Adults

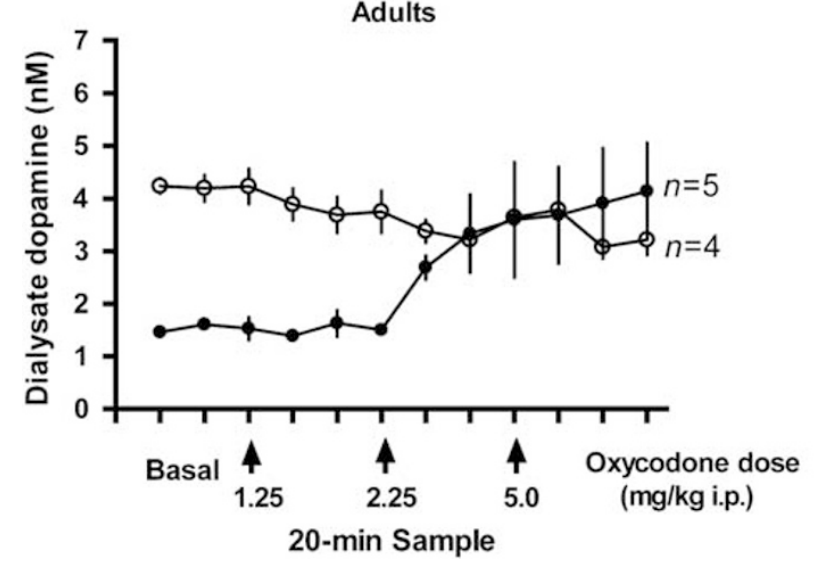

Adult

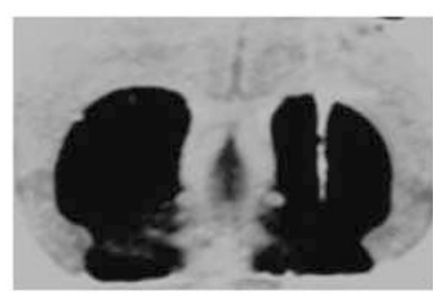

Figure 4 The levels of dopamine in the dialysate from the striatum of mice from each 20 min sample during the baseline, and in the hour after each injection, in younger and older mice which had self-administered oxycodone or were yoked saline controls, are shown in (a). Arrows indicate the time and dose of oxycodone challenge injections (or saline administrations). Placement of the dialysis probes is shown in (b). Upper panel: the micrograph shows the probe placement in the striatum of a representative adolescent mouse used in this study. Lower panel: the micrograph shows the probe placement in the striatum of a representative adult mouse used in the current study. 

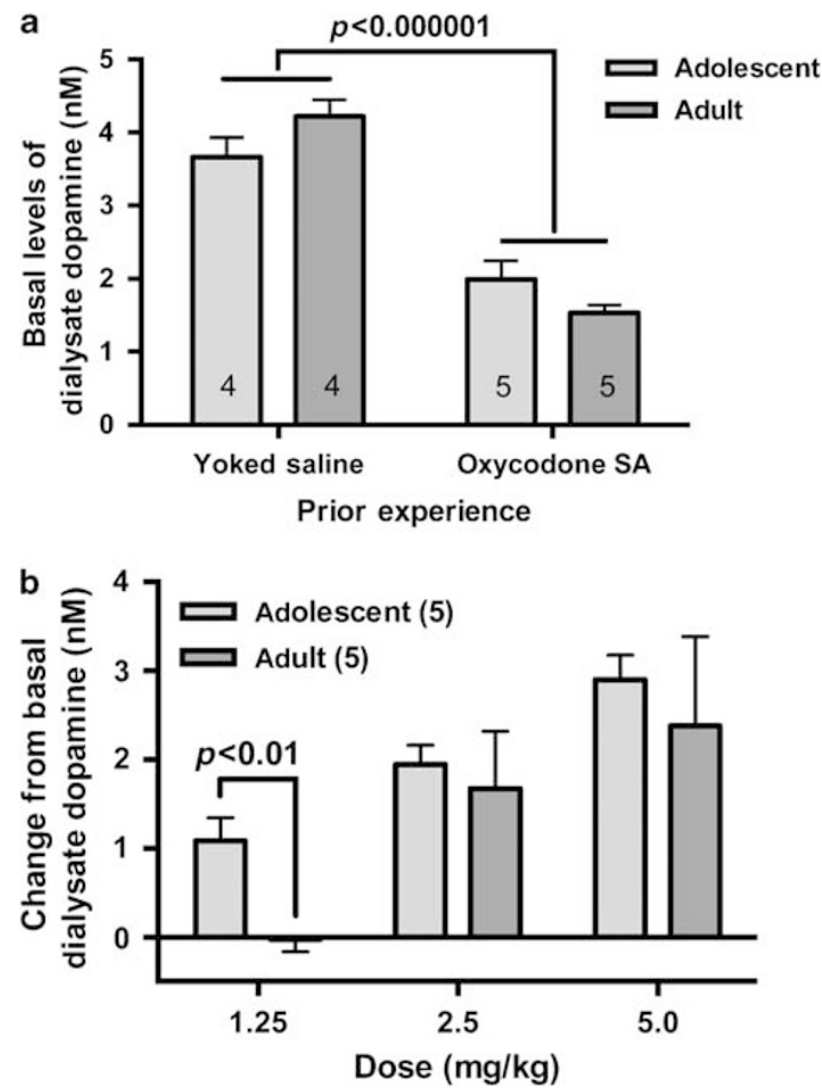

Figure 5 The effects of previous oxycodone self-administration on basal striatal dopamine levels is shown in (a). Mice that had earlier selfadministered oxycodone showed significantly lower basal dopamine levels than yoked saline controls which had received only saline infusions in both age groups, $p<0.00000 \mathrm{l}$. There was also a significant interaction of preexposure $\times$ age, $p<0.05$. The effect of oxycodone self-administration during adolescence or in adulthood on striatal dopamine levels after oxycodone challenge injections I week later expressed as change from basal levels (mean of the 20 min samples) is shown in (b). There was a significant main effect of dose, $p<0.0005$, across age groups. However, only the mice exposed to oxycodone as adolescents showed an increase in striatal dopamine levels in response to the lowest dose of oxycodone tested; the adult group did not, $p<0.05$ between age groups, planned comparison.

administered, the lower the increases of dopamine levels in response to oxycodone challenge a week later.

\section{Experiment 2: Oxycodone Dose-Response and Extinction}

The upper panel of Figure 7 shows the number of selfadministered oxycodone infusions at five doses of oxycodone $(0,0.75,0.5,0.25$, and $0.125 \mathrm{mg} / \mathrm{kg}$ per infusion) by mice whose starting dose followed a Latin square design, in both the adolescents and adults. Two-way ANOVA, age $\times$ dose, showed again that adolescents self-administered fewer oxycodone infusions than adults across doses. There was a significant main effect of age, $\mathrm{F}(1,10)=13.98$, $p<0.005$, there was a significant effect of dose, $\mathrm{F}(4,40)=44.11, p<0.000001$, with no significant interaction, $\mathrm{F}(4,40)=1.82, p=0.145$.

The lower panel of Figure 7 presents the mean $( \pm$ SEM) number of nose pokes at the active hole during the seven

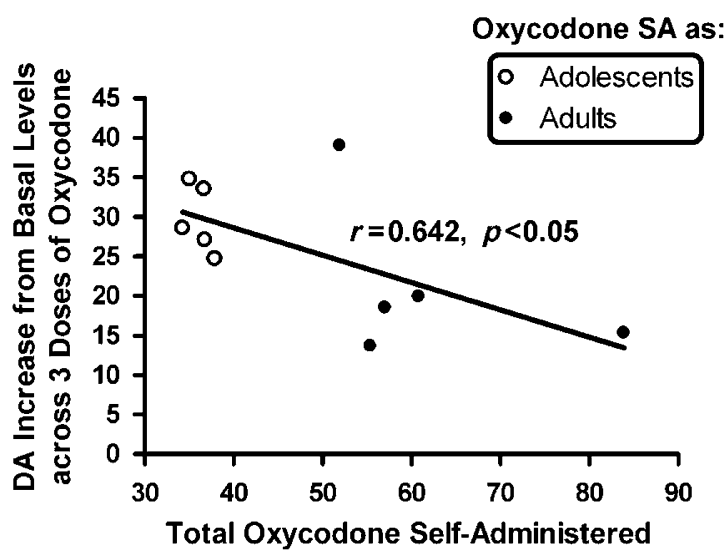

Figure 6 The correlation between oxycodone induced an increase in striatal dopamine levels with earlier total oxycodone self-administered. The three doses of oxycodone administered revealed a significant negative correction between the total amounts of oxycodone self-administered and oxycodone-induced increase in striatal dopamine levels, $r=0.642, p<0.05$. There was a significant negative correlation between increases from basal dopamine levels in dopamine across the three ascending doses of oxycodone injections and the total amount of oxycodone that had been self-administered a week later. Mice who were adolescents during oxycodone self-administration are shown with different symbols than those who were adults.

extinction sessions. Two-way ANOVA, age $\times$ session, revealed that there was no significant main effect of age, $\mathrm{F}(1,8), p<1.00$, there was a significant effect on sessions, $\mathrm{F}(6,68)=16.01, p<0.000001$, with no significant age $\times$ session interaction, $\mathrm{F}(6,48)=1.16, p=0.34$.

\section{DISCUSSION}

The rewarding effects of drugs of abuse in adolescent compared with adult rodents were studied in other drugs of abuse. For instance, no difference in acquisition of cocaine self-administration between periadolescent and adult Wistar rats was found (Frantz et al, 2007). Also, early and late adolescent and young adult rats developed conditioned place preference to cocaine $(20 \mathrm{mg} / \mathrm{kg}$, i.p.) (Badanich et al, 2006). Behavioral differences between adolescent and adult rats induced by reinforcing effects of nicotine have been examined in several studies with conflicting results. Adolescents show either enhanced or reduced conditioned place preference to nicotine depending on age and dose (Vastola et al, 2002; Belluzzi et al, 2004). Some studies found that adolescent rats self-administered more nicotine than adult rats (Levin et al, 2003, 2007; Chen et al, 2007). Others found there were no age differences in nicotine selfadministration under FR1 or FR2 schedules, but nicotine self-administration was higher in adult than in adolescent rats under higher FR schedules (Belluzzi et al, 2005; Shram et al, 2008). Further, in one study, nicotine intake in adolescent rats was significantly lower compared with adults at the highest dose of nicotine tested (Shram et al, 2008). Differences in training (food restriction and shaping), length of drug access period, FR schedules, strains (Lewis, Sprague-Dawley, or Long-Evans), and age and 
a Oxycodone self administration

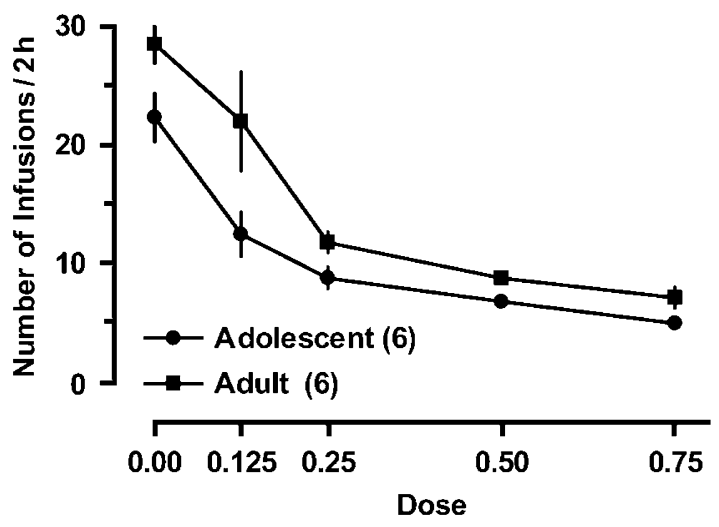

b

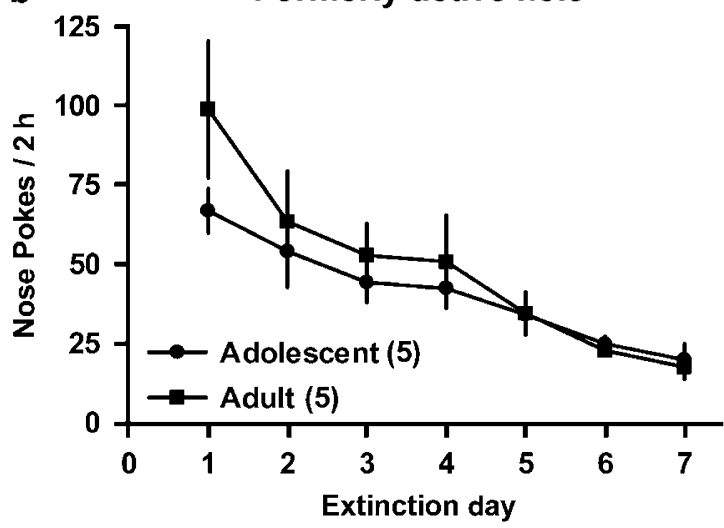

Figure 7 The number of self-administered oxycodone infusions at five doses of oxycodone $(0,0.75,0.5,0.25$, and $0.125 \mathrm{mg} / \mathrm{kg}$ per infusion) with a Latin square design in both the adolescent and adult mice is shown in the upper panel. (a) Two-way ANOVA, age $\times$ dose, showed that adolescents self-administered fewer oxycodone infusions than adults across doses. There was a significant main effect of age, and there was a significant effect of dose with no significant age $\times$ dose interaction. The lower panel (b) presents the mean $( \pm$ SEM) number of nose pokes at the active hole during the seven extinction sessions. Two-way ANOVA, age $\times$ session revealed that there was no significant difference between the two age groups.

sex of animals studied may account for these conflicting results.

It has been reported that adolescent rats are less responsive to the locomotor-stimulating effects of psychostimulants such as amphetamine and cocaine than adults (eg Adriani et al, 2003; Spear and Brick, 1979). In a study in rats examining cocaine- or morphine-induced conditioned place preference, no significant differences between adolescent and adult place conditioning were found when drug exposure was paired to the nonpreferred chamber (Campbell et al, 2000). Other studies found that periadolescent rats exhibited more morphine-induced ( $10 \mathrm{mg} / \mathrm{kg}$, i.p.) crossings and grooming than adult rats (Spear et al, 1982), and younger rats exposed repeatedly to morphine between P30 and P32 demonstrated higher levels of locomotor sensitization than P65 and P67 adults (White and Holtzman, 2005). In the studies of nicotine, adolescent rats were more sensitive to locomotor-stimulating effects induced by acute and chronic nicotine (Schochet et al, 2004; Faraday et al, 2001, 2003). However, adolescents showed less locomotor sensitization induced by nicotine than adult rats (Schochet et al, 2004; Cruz et al, 2005).

In this study of the opioid oxycodone, adolescent mice self-administered a lower number of oxycodone infusions than the adult mice during both the FR1 acquisition phase, and in the dose-response study. Lower levels of selfadministration by the adolescent mice may indicate a lowerreinforcing effect of oxycodone compared with adults. Such an interpretation was given in a nicotine study that found adolescents self-administered less nicotine than adults (Shram et al, 2008). However, the lower number of selfadministered infusions of oxycodone by the adolescent mice may be associated with an enhanced response to oxycodone. This interpretation is supported by the finding of increased striatal dopamine in response to the lowest dose of oxycodone only in the mice that had selfadministered oxycodone during adolescence, not in those that had self-administered as adults. Furthermore, in spite of the fact that they had self-administered the lower doses of oxycodone, adolescents later showed the greatest increases in striatal dopamine levels across the three doses of experimenter-administered oxycodone.

It is possible that the difference in response to oxycodone in adolescent mice may be associated with the differential effects of isolation on adolescent $v s$ adult mice (from group housing to individual housing for the remainder of the experiment after catheter implantation), as it has been reported that housing conditions during adolescence affected cocaine self-administration in the young adult rat (Schenk et al, 1987).

During the acquisition phase, responses in the adult and adolescent were increased when the FR was increased. However, under the FR3 schedule, the total dose consumed was reduced in the adults but not in the adolescents. This suggests that when the work load increased, adults were less inclined to obtain the drug, whereas the adolescents maintained approximately the same level of intake irrespective of the increased schedule, indicating at least the same level of motivation. In the dose-response study, the response was higher for saline than for oxycodone. This probably represented an 'extinction burst'. The greater response in adults was likely due to the enhanced motivation for oxycodone seeking in the adults relative to adolescents. The fact that mice nose poked more immediately after drug was replaced with saline during the extinction period, shows that oxycodone was being actively self-administered.

Earlier studies found that basal dopamine levels are age dependent. For instance, the basal dopamine levels on PND 35 are lower than those of young adults on PND 60 . Interestingly, basal dopamine levels on PND 45 are higher than on PND 60 (Badanich et al, 2006). In addition, the rates of dopamine release and uptake were higher in adults than in young rats as measured by fast cyclic voltammetry (Stamford, 1989). In the study reported herein, basal striatal dopamine levels of mice with no previous exposure to oxycodone were found to be similar in both age groups. This is consistent with results from another study showing that there was no age-related difference in basal dopamine levels in the nucleus accumbens (Frantz et al, 2007).

The effects of repeated exposure to opioids on basal dopamine levels have been examined before. Opioid 
administration leads to decreases in dopamine levels in the nucleus accumbens in adult rats during withdrawal (Pothos et al, 1991; Rossetti et al, 1992; Diana et al, 1995). Interestingly, repeated self-administration of heroin also caused a decrease in basal dopamine levels in the nucleus accumbens in adult rats (eg Gerrits et al, 2002). When another addictive drug, cocaine, was administered in a 'binge' pattern, it was found to decrease basal dopamine levels in both the nucleus accubmens and caudate putamen in rats (Maisonneuve et al, 1995), and in mice (Zhang et al, 2003).

In the current study, lowered basal striatal dopamine levels were found not only in mice that had selfadministered oxycodone as adults, but also in mice that had previously self-administered oxycodone during adolescence. Adolescent rodents have been found to express more dopamine receptors in striatal regions (Teicher et al, 1995; Tarazi et al, 1998, 1999, 2000). However, these neurochemical differences between adolescents and adults decline by the end of the period of adolescence, which corresponds to the time when the in vivo microdialysis study reported here was performed, and may explain, in part, why earlier oxycodone self-administration affected basal striatal dopamine levels in a similar way in the two age groups.

Adolescent cannabis exposure has been reported to enhance heroin intake and increase striatal preproenkephalin mRNA levels in the adult rat (Ellgren et al, 2007). Also, pretreatment with cocaine during adolescence was found to enhance the response of the dopaminergic system to a natural reinforcer, sucrose, in rats (Catlow and Kirstein, 2007). These studies may reflect an effect of a drug on the reward system of the adolescent that increases rewarding properties of substances later in adulthood, that is, that leads to greater vulnerability to drugs of abuse.

The current study found that oxycodone induced an increase in striatal dopamine levels in a dose-dependent manner across the two age groups. It should be noted that the microdialysis study was conducted 1 week after behavior analysis, when the adolescent mice had become young adults. However, the lowest dose tested $(1.25 \mathrm{mg} / \mathrm{kg})$ increased striatal dopamine levels only in mice that had self-administered oxycodone during adolescence, but not as adults. This result shows that such preexposure to oxycodone during adolescence enhances the ability of oxycodone to increase striatal dopamine levels relative to adult exposure. Oxycodone exposure during adolescence resulted in long-lasting functional alterations in the nigrostriatal dopaminergic system. Possible underlying mechanisms for this effect include overexpression of dopamine receptors and/or enhancement in $\mu$-opioid receptor function in the brain due to fluctuation in the levels of dopamine receptors (Teicher et al, 1995; Tarazi et al, 1998, 1999, 2000) and/or functional changes in the $\mu$-opioid receptors from adolescence to young adulthood (Talbot et al, 2005). In addition, alterations in the dynorphin and $\kappa$-opioid receptor systems between the age groups may be involved as one study found that intermittent morphine increased preprodynorphin and $\kappa$-opioid receptor mRNA levels in the rat brain (Wang et al, 1999). These neurochemical changes may underlie the higher behavioral sensitivity found in the adolescent mice.

Oxycodone produces its rewarding effects by acting primarily on $\mu$-opioid receptors in the nigrostriatal and mesolimbic dopaminergic systems (Narita et al, 2008). It is possible that $\mu$-opioid receptor density or function in the adolescent is different than in the adult, leading to the differences found in oxycodone self-administration and later oxycodone induced an increase in dopamine levels at the lowest dose tested. Indeed, $\mu$-opioid receptor-stimulating $\left[{ }^{35} \mathrm{~S}\right] \mathrm{GTP} \gamma \mathrm{S}$ binding increased from 0.13 to $3.6 \mathrm{fmol} / \mathrm{mg}$ tissue between PND five and adulthood (Talbot et al, 2005). As there are few studies examining these differences in opioid receptors, directly comparing $\mu$-opioid receptors in the adolescent brain with those in the adult brain in rodents would be of interest for future study.

This study is the first to directly compare the effects of the prescription opioid oxycodone in adolescent and adult mice on self-administration, and subsequent effects of oxycodone administration on striatal dopamine levels. We found that adult mice self-administered significantly more oxycodone than did the adolescent mice, during the acquisition phase and in the dose-response study. Mice that had selfadministered oxycodone in both age groups were found to have decreased basal striatal dopamine levels, and oxycodone led to increased striatal dopamine levels in a dosedependent manner across both age groups. However, in response to the lowest dose of experimenter-administered oxycodone tested, there was a significant increase in striatal dopamine levels in mice that had self-administered oxycodone during adolescence, but not in mice that had self-administered oxycodone as adults. Taken together, these results suggest that oxycodone-induced rewarding effects differed between adolescent and adult mice. Further, they demonstrate a potential mechanism (increased sensitivity of adolescents to oxycodone, as shown by increased striatal dopamine at the lowest dose tested) that could lead to further self-administration. Elucidation of behavioral and neurobiological changes induced by oxycodone, particularly in the developmental period of adolescence, should help to understand mechanisms leading to oxycodone addiction in humans, and should lead to better strategies for prevention and therapeutic approaches to dependence and addiction to prescription opioids.

\section{ACKNOWLEDGEMENTS}

This work was supported by NIH-NIDA P60 DA05130 to Dr Mary Jeanne Kreek.

\section{DISCLOSURE/CONFLICT OF INTEREST}

The authors declare that, except for income received from the primary employer, no financial support or compensation has been received from any individual or corporate entity over the past 3 years for research or professional service and there are no personal financial holdings that could be perceived as constituting a potential conflict of interest.

\section{REFERENCES}

Adriani W, Seta DD, Dessi-Fulgheri F, Farabollini F, Laviola G (2003). Altered profiles of spontaneous novelty seeking, impulsive behavior, and response to D-amphetamine in rats 
perinatally exposed to bisphenol A. Environ Health Perspect 111: 395-401.

Badanich KA, Adler KJ, Kirstein CL (2006). Adolescents differ from adults in cocaine conditioned place preference and cocaine-induced dopamine in the nucleus accumbens septi. Eur J Pharmacol 550: 95-106.

Belluzzi JD, Lee AG, Oliff HS, Leslie FM (2004). Age-dependent effects of nicotine on locomotor activity and conditioned place preference in rats. Psychopharmacology (Berl) 174: 389-395.

Belluzzi JD, Wang R, Leslie FM (2005). Acetaldehyde enhances acquisition of nicotine self-administration in adolescent rats. Neuropsychopharmacology 30: 705-712.

Campbell JO, Wood RD, Spear LP (2000). Cocaine and morphineinduced place conditioning in adolescent and adult rats. Physiol Behav 68: 487-493.

Catlow BJ, Kirstein CL (2007). Cocaine during adolescence enhances dopamine in response to a natural reinforcer. Neurotoxicol Teratol 29: 57-65.

Chen H, Matta SG, Sharp BM (2007). Acquisition of nicotine selfadministration in adolescent rats given prolonged access to the drug. Neuropsychopharmacology 32: 700-709.

Cherny NI (1996). Opioid analgesics: comparative features and prescribing guidelines. Drugs 51: 713-737.

Cruz FC, Delucia R, Planeta CS (2005). Differential behavioral and neuroendocrine effects of repeated nicotine in adolescent and adult rats. Pharmacol Biochem Behav 80: 411-417.

Diana M, Pistis M, Muntoni A, Gessa G (1995). Profound decrease of mesolimbic dopaminergic neuronal activity in morphine withdrawn rats. J Pharmacol Exp Ther 272: 781-785.

Ellgren M, Spano SM, Hurd YL (2007). Adolescent cannabis exposure alters opiate intake and opioid limbic neuronal populations in adult rats. Neuropsychopharmacology 32: 607-615.

Faraday MM, Elliott BM, Grunberg NE (2001). Adult vs adolescent rats differ in biobehavioral responses to chronic nicotine administration. Pharmacol Biochem Behav 70: 475-489.

Faraday MM, Elliott BM, Phillips JM, Grunberg NE (2003). Adolescent and adult male rats differ in sensitivity to nicotine's activity effects. Pharmacol Biochem Behav 74: 917-931.

Franklin KBJ, Paxinos G (1997). The Mouse Brain in Stereotaxic Coordinates. Academic Press Inc.: New York.

Frantz KJ, O'Dell LE, Parsons LH (2007). Behavioral and neurochemical responses to cocaine in periadolescent and adult rats. Neuropsychopharmacology 32: 625-637.

Gerrits MA, Petromilli P, Westenberg HG, Di Chiara G, van Ree JM (2002). Decrease in basal dopamine levels in the nucleus accumbens shell during daily drug-seeking behaviour in rats. Brain Res 924: 141-150.

Hemby SE, Martin TJ, Co C, Dworkin SI, Smith JE (1995). The effects of intravenous heroin administration on extracellular nucleus accumbens dopamine concentrations as determined by in vivo microdialysis. J Pharmacol Exp Ther 273: 591-598.

Johnston LD, O'Malley PM, Bachman JG, Schulenberg JE (2006). Monitoring the Future: National Results on Adolescent Drug Use. Overview of Key Findings, 2006. National Institute on Drug Abuse. NIDA 76.

Levin ED, Lawrence SS, Petro A, Horton K, Rezvani AH, Seidler FJ et al (2007). Adolescent $v s$ adult-onset nicotine self-administration in male rats: duration of effect and differential nicotinic receptor correlates. Neurotoxicol Teratol 29: 458-465.

Levin ED, Rezvani AH, Montoya D, Rose JE, Swartzwelder HS (2003). Adolescent-onset nicotine self-administration modeled in female rats. Psychopharmacology (Berl) 169: 141-149.

Maisonneuve IM, Ho A, Kreek MJ (1995). Chronic administration of a cocaine 'binge' alters basal extracellular levels in male rats: an in vivo microdialysis study. J Pharmacol Exp Ther 272: 652-657.
Merrill JC, Kleber HD, Shwartz M, Liu H, Lewis SR (1999). Cigarettes, alcohol, marijuana, other risk behaviors, and American youth. Drug Alcohol Depend 56: 205-212.

Narita M, Nakamura A, Ozaki M, Imai S, Miyoshi K, Suzuki M et al (2008). Comparative pharmacological profiles of morphine and oxycodone under a neuropathic pain-like state in mice: evidence for less sensitivity to morphine. Neuropsychopharmacology 33: 1097-1112.

Nicholson B (2003). Responsible prescribing of opioids for the management of chronic pain. Drugs 63: 17-32.

Pothos E, Rada P, Mark GP, Hoebel BG (1991). Dopamine microdialysis in the nucleus accumbens during acute and chronic morphine, naloxone-precipitated withdrawal and clonidine treatment. Brain Res 566: 348-350.

Rossetti ZL, Hmaidan Y, Gessa GL (1992). Marked inhibition of mesolimbic dopamine release: a common feature of ethanol, morphine, cocaine and amphetamine abstinence in rats. Eur J Pharmacol 221: 227-234.

Schenk S, Lacelle G, Gorman K, Amit Z (1987). Cocaine selfadministration in rats influenced by environmental conditions: implications for the etiology of drug abuse. Neurosci Lett 81: 227-231.

Schochet TL, Kelley AE, Landry CF (2004). Differential behavioral effects of nicotine exposure in adolescent and adult rats. Psychopharmacology (Berl) 175: 265-273.

Shelley K, Paech MJ (2008). The clinical applications of intranasal opioids. Curr Drug Deliv 5: 55-58.

Shram MJ, Funk D, Li Z, Le AD (2008). Nicotine self-administration, extinction responding and reinstatement in adolescent and adult male rats: evidence against a biological vulnerability to nicotine addiction during adolescence. Neuropsychopharmacology 33: 739-748.

Spear LP, Brick J (1979). Cocaine-induced behavior in the developing rat. Behav Neural Biol 26: 401-415.

Spear LP, Horowitz GP, Lipovsky J (1982). Altered behavioral responsivity to morphine during the periadolescent period in rats. Behav Brain Res 4: 279-288.

Stamford JA (1989). Development and ageing of the rat nigrostriatal dopamine system studied with fast cyclic voltammetry. J Neurochem 52: 1582-1589.

Talbot JN, Happe HK, Murrin LC (2005). Mu opioid receptor coupling to Gi/o proteins increases during postnatal development in rat brain. J Pharmacol Exp Ther 314: 596-602.

Tarazi FI, Campbell A, Yeghiayan SK, Baldessarini RJ (1998). Localization of dopamine receptor subtypes in corpus striatum and nucleus accumbens septi of rat brain: comparison of D1-, D2-, and D4-like receptors. Neuroscience 83: 169-176.

Tarazi FI, Tomasini EC, Baldessarini RJ (1999). Postnatal development of dopamine D1-like receptors in rat cortical and striatolimbic brain regions: an autoradiographic study. Dev Neurosci 21: 43-49.

Tarazi FI, Zhang K, Baldessarini RJ (2000). Effects of nigrostriatal dopamine denervation on ionotropic glutamate receptors in rat caudate-putamen. Brain Res 881: 69-72.

Teicher MH, Andersen SL, Hostetter Jr JC (1995). Evidence for dopamine receptor pruning between adolescence and adulthood in striatum but not nucleus accumbens. Brain Res Dev Brain Res 89: $167-172$.

Vastola BJ, Douglas LA, Varlinskaya EI, Spear LP (2002). Nicotineinduced conditioned place preference in adolescent and adult rats. Physiol Behav 77: 107-114.

Wang XM, Zhou Y, Spangler T, Ho A, Han JS, Kreek MJ (1999). Acute intermittent morphine increases preprodynorphin and kappa opioid receptor mRNA levels in the rat brain. Brain Res Mol Brain Res 20: 184-187.

White DA, Holtzman SG (2005). Periadolescent morphine exposure alters subsequent behavioral sensitivity to morphine in adult rats. Eur J Pharmacol 528: 119-123. 
Wise RA, Leone P, Rivest R, Leeb K (1995). Elevations of nucleus accumbens dopamine and DOPAC levels during intravenous heroin self-administration. Synapse 21: 140-148.

Yu J, Williford WR (1992). The age of alcohol onset and alcohol, cigarette, and marijuana use patterns: an analysis of drug use progression of young adults in New York State. Int J Addict 27: 1313-1323.

Zhang Y, Schlussman SD, Ho A, Kreek MJ (2001). Effect of acute binge cocaine on levels of extracellular dopamine in the caudate putamen and nucleus accumbens in male C57BL/6J and 129/J mice. Brain Res 923: 172-177.

Zhang Y, Schlussman SD, Ho A, Kreek MJ (2003). Effect of chronic 'binge cocaine' on basal levels and cocaine-induced increases of dopamine in the caudate putamen and nucleus accumbens of C57BL/6J and 129/J mice. Synapse 50: 191-199.

Zhang Y, Svenningsson P, Picetti R, Schlussman SD, Nairn AC, Ho A et al (2006). Cocaine self-administration in mice is inversely related to phosphorylation at Thr34 (protein kinase A site) and Ser130 (kinase CK1 site) of DARPP-32. J Neurosci 26: 2645-2651. 